\title{
Effect of Organic Manures and Inorganics Fertilizers on Growth and Yield of Bottle Gourd (Lagenaria siceraria Mol.) standl
}

\author{
Medipalli Pravallika* and Deepanshu \\ Department of Horticulture, Naini Agricultural Institute, STUATS, Prayagraj, \\ Uttar Pradesh, India \\ *Corresponding author
}

\begin{abstract}
A B S T R A C T
\end{abstract}

\begin{tabular}{l} 
K e y w o r d s \\
Bottle gourd, \\
Organic (FYM, \\
Vermicompost, \\
Poultry manure, \\
Inorganic (NPK) \\
\hline Article Info \\
$\begin{array}{l}\text { Accepted: } \\
\text { 18 November } 2020 \\
\text { Available Online: } \\
\text { 10 December } 2020\end{array}$ \\
\hline
\end{tabular}

The present experiment was carried out during August to October 2019 in Research field, Department of Horticulture, SHUATS, Prayagraj. The experiment was conducted in factorial Randomized Block Design (RBD), with 13 treatments, replicated thrice with organic (FYM, Vermicompost, Poultry Manure) \& Inorganic (NPK) on bottle gourd. $\mathrm{T}_{0}$ control $\left[\mathrm{RND}(\mathrm{RDF}(120: 60: 60 \mathrm{Kg}\right.$ NPK$)+20 \mathrm{t}+\mathrm{FYM}], \mathrm{T}_{1} 100 \%$ RND through chemical fertilizer, $\mathrm{T}_{2} 100 \% \mathrm{RDF}+10 \mathrm{t}$ vermicompost, $\mathrm{T}_{3} 100 \% \mathrm{RDF}+5 \mathrm{t}$ poultry manure, $\mathrm{T}_{4} 75 \%$ $\mathrm{RDF}+25 \%$ through FYM, $\mathrm{T}_{5} 75 \% \mathrm{RDF}+25 \%$ through $\mathrm{FYM}, \mathrm{T}_{6} 75 \% \mathrm{RDF}+25 \%$ through vermicompost, $\mathrm{T}_{7} 75 \% \mathrm{RDF}+25 \%$ through poultry manure, $\mathrm{T}_{8} 75 \% \mathrm{RDF}+25 \%$ through (vermicompost + poultry manure), $\mathrm{T}_{9} 50 \% \mathrm{RDF}+50 \%$ through $\mathrm{FYM}, \mathrm{T}_{10} 50 \%$ $\mathrm{RDF}+50 \%$ vermicompost, $\mathrm{T}_{11} 50 \% \mathrm{RDF}+50 \%$ through poultry manure, $\mathrm{T}_{12} 50 \% \mathrm{RDF}+$ $50 \%$ through (vermicompost + poultry manure) from the present experiment, it is found that Treatment 12 combination of $50 \%$ RDF of NPK $+50 \%$ through (vermicompost + Poultry manure), was found best in terms of growth, yield and quality parameters of bottle gourd, followed by $\mathrm{T}_{8} 75 \% \mathrm{RDF}+25 \%$ through (vermicompost + poultry manure). In terms of benefit cost ratio $\mathrm{T}_{12}(1: 3.28)$ was found maximum Whereas minimum $\mathrm{B}: \mathrm{C}$ ratio was recorded in $\mathrm{T}_{0}(1: 1.28)$ control [RND (RDF $\left.(120: 60: 60 \mathrm{~kg} \mathrm{NPK})+20 \mathrm{t}+\mathrm{FYM}\right]$.

\section{Introduction}

Bottle gourd Lagenaria siceraria Mol. Standl. $(2 \mathrm{n}=22)$ is an important cucurbitaceous crop grown throughout the country. It is a warm season vegetable, which thrives well in warm and humid climate but it can be grown throughout the year in Northern India as offseason vegetable.

The young and tender fruit of bottle gourd are mostly used in rayata, halwa, petha etc. dry shells of the mature fruits are used to make containers and musical instruments.

Vegetable are important nutritive component of the daily diet because their nutritive value as vital source of vitamins and minerals which has been well recognized.

Vegetable play an important role in the balance diet by providing not only energy but also supplying vita protective nutrition either mineral or vitamins. Thus, vegetables are 
getting increasingly higher important in India as well as in the world due to their relevance in achieving nutritional security from emerging nutritional problems in human beings. Today, India is the second largest producer of vegetable in worlds after china.

According to recommendation given by India Council of Medical Research (ICMR) an average man with vegetarian or Nonvegetarian food habit should consume $300 \mathrm{~g}$ vegetable per day, which includes $125 \mathrm{mg}$ leafy vegetable, $100 \mathrm{~g}$ of root vegetable and $75 \mathrm{~g}$ of other vegetable. In the year 2002, the total vegetable production of country was 97.5 million tonnes from 7.59 million hectares of land (Gupta et al., 2010). In the country, vegetable crops are grown only in 2.8 percent of total cultivated land and share 10 percent of the world's vegetable production with productivity of 13.6 tha $^{-1}$, which is quite low as compared to other advanced countries.

All cucurbits are botanically 'pepo' belong to the family cucurbitacece. These are used in the form of Salad Cucumber and long melon), Desert fruits (Musk Melon and Water Melon) cooked as vegetable (bottle gourd). Bitter gourd and sponge gourd) and preserved in the form of sweets (petha and pointed gourd). Cucurbits are the largest groups of summer seasons vegetable and extensively grown in tropical, subtropical and temperate zones of India. It has been important to man as a source of food and utensil since the down civilization. Biochemically the cucurbits are characterized by bitter.

Today agriculture is based on the use of inorganic manures, which play a major role for producing higher yield in per unit area. These are commonly used by most of the farmers because of quick availability of nutrient to the plant and easily available in market. Organic manures increase the organic matter in the soil. They provide organic acids that help dissolve soil nutrients and make them available for the plants. Application of organic manures improves the soil fertility, soil structure and moisture holding capacity.

Integrated plant nutrient management is one of the recent methods of supplying nutrients to the plants by organic as well as inorganic means together to fulfil the nutrient requirements. At the same time the main aim of integrated plant nutrient management is to minimize the use of chemical fertilizers without sacrificing the yield. Composts, vermicompost, poultry manures, Farmyard manure (FYM) etc. are bulky organic manures, although supply low quality of major nutrients, but have potential to supply all essential nutrients for longer periods. Integrated plant nutrient management (IPNM) is the best approach for obtaining potential crop yield with less expenditure.

The optimum dose of nitrogen, phosphorus, and potassium vary greatly cultivar, geographical location and the environmental factors. These factors will have marked effect on the growth and yield parameters of bottle gourd. A judicious use of organic manures, chemical fertilizers and biofertilizers may be effective not only in sustaining crop productivity and soil health, but also in supplementing chemical fertilizers, requirements of the crops.

\section{Materials and Methods}

The experiment was conducted during rainy season of the year 2019 in Departmental research field of Department of Horticulture and Sciences, Prayagraj. The area is situated on the south of Prayagraj on the right bank of Yamuna at Rewa Road at a distance of about $6 \mathrm{~km}$ from Prayagraj city. It is situated at $250.8^{\circ} \mathrm{N}$ latitude and $810.50^{\circ} \mathrm{E}$ longitudes on elevation of 98 meters from the sea level. 
The area of prayagraj district comes under subtropical belt in the south east of Uttar Pradesh, which experience extremely hot summer and fairly cold winter. The maximum temperature of the location reaches up to $46^{\circ} \mathrm{C}$ $-48^{\circ} \mathrm{C}$ and seldom falls as low as $40 \mathrm{C}-50 \mathrm{C}$. the relative humidity ranges between 20 to 94 percent. The average rainfalls in this area are around $1013.4 \mathrm{~mm}$ annually.

The experimental field has an even topography with a gentle slope and good drainage. The sample were drawn from each replication of experimental plot at $0-15 \mathrm{~cm}$ depth before sowing of the crop and a composite sample was made to determine the physical and chemical properties of soil. The mechanical analysis of the sample soil was done with the half of Bouyoucos hydrometer (1952) method. It is evident from table 1 the soil of the experiment plot was sandy loam in texture, poor in phosphorus and rich in potash. The $\mathrm{pH}$ of the soil is slightly towards alkalinity.

\section{Results and Discussion}

The morphological, growth, yield and quality characteristics of the bottle gourd, namely vine length $(\mathrm{m})$, number of branches per plant, days to first male flower appearance, days to first female flower appearance, days to first picking, average fruit length $(\mathrm{cm})$, average fruit weight $(\mathrm{g})$, diameter of the fruit (cm), number of fruits per plant, average yield (tonne/ha), TSS and vitamin $\mathrm{C}$ were affected by the combined application of FYM, NPK, Vermicompost and Poultry manure.

Application of these individual fertilizers without combination did not have significant increase of yield and related traits but with the great combination of fertilizers and organic manures had significantly increased yield in bottle gourd. The data related to various growth, yield and quality traits in bottle gourd are presented in Table 2 and that regarding benefit cost ratio were presented in Table 3. Application of recommended dose of fertilizers along with 20 tonnes of FYM had showed the retorted growth, yield and quality of the bottle gourd compared to all other treatment combinations namely vine length $(4.57 \mathrm{~m})$, number of branches per plant (7.88), average fruit length $(25.7 \mathrm{~cm})$, average fruit weight $(1.28 \mathrm{~g})$, diameter of fruit $(14.57 \mathrm{~cm})$, number of fruits per plant (9.41), fruit yield per plant $(12.03 \mathrm{~kg})$, average yield (15.27tonnes/ha), TSS (2.65) and vitamin C $(5.16 \%)$. Whereas, highest vine length observed in case of $\mathrm{T}_{12}$ followed by $\mathrm{T}_{8}$ and $\mathrm{T}_{9}$ but lowest vine length was observed in $\mathrm{T}_{0}$ (control). These results are in consonance with Nagar et al., 2017 and Nitin and Saravanan, 2019.

\section{Impact of different nutrient treatment on growth characters of bottle gourd}

Integrated management for nutritional balance had an important impact on all growth, yield and quality characteristics (Table 2). Significantly the highest vine length $(7.46 \mathrm{~m})$, number of branches per plant (12.44), were reported in 50 percent $\mathrm{RDF}+50$ percent through (vermicompost + poultry manure) $\left(T_{12}\right)$ followed by vine length (7.39), number of branches per plant (12.31) in 75 percent $\mathrm{RDF}+25$ percent through (vermicompost + poultry manure) $\left(\mathrm{T}_{8}\right)$ while the lowest vine length $(4.57 \mathrm{~m})$, number of branches per plant (7.88) were recorded in control $\left(\mathrm{T}_{0}\right)$. The mixture of NPK, vermicompost and poultry manure promotes root development by efficiently translocating growth-promoting compounds synthesized in plants, accompanied by increased absorption of nutrients. Due to the growth of large photosynthetic areas containing the largest vine length and a larger number of branches per plant, the rate of different physiological and biochemical processes increased. These findings are in agreement with Sangeetha et al., (2018) in bitter gourd, Satish et al., (2017) 
and Das et al., (2015).

Improved photosynthetic actions in a wide photosynthertic area resulted in better growth parameters this may be due to increased dose of fertilizer to boost the vegetative properties of bottle gourd. Balai et al., (2017) and Nagar et al., (2017) have reported comparable work on bottle gourd species. The combined application of inorganic and organic manures had a big impact on bottle gourd growth parameters. This was due to higher nutrient supply and increased organic manure along with inorganic fertilizer particularly nitrogen, which had a profound effect on the mobilization of nutrients from the unavailable nutrient form, primarily due to enhanced soil physical, chemical and biological properties. The use of organic manure may contribute to an increase in growth parameters, such as the length of the vine and the number of branches, which facilitates the rapid and increased availability of plant nutrients and thus provides a better environment for root growth and proliferation. More adsorbent surface is also created for nutrient uptake.

\section{Impact of different nutrient treatment on flowering characters of bottle gourd}

The flowering traits like days to first male flower appearance and days to first female flower appearance have been presented in Table 2. The first and earliest male flower were appeared in $\mathrm{T}_{12}$ (68 Days) (50\% RDF + $50 \%$ through (Vermicompost + poultry manure) followed by $\mathrm{T}_{8}$ (69 days) (75\% RDF $+25 \%$ through (vermicompost + poultry manure) and late male flowering was observed in $\mathrm{T}_{0}$ (82 days) (control) while significantly minimum days to first and earliest female flower appearance was found in $\mathrm{T}_{12}$ (72 days) followed by $\mathrm{T}_{8}$ (74 days) whereas, maximum days taken for first male and female flower appearance (82.20 and 86.66 days, respectively) were with treatment combination of RDF of NPK and 20 tonnes of $\operatorname{FYM}\left(\mathrm{T}_{0}\right)$.

Table.1 Treatment Combination details used in present experiment

\begin{tabular}{|c|l|}
\hline Treatments symbols & \multicolumn{1}{|c|}{ Treatment combinations } \\
\hline $\mathbf{T}_{\mathbf{0}}$ & Control [RND (RDF (120: 60: 60 kg NPK) + 20t FYM] \\
\hline T1 & 100\% RND through chemical fertilizers \\
\hline T2 & 100\% RDF + 10t vermicompost \\
\hline T3 & 100\% RDF +5t Poultry manure \\
\hline T4 & 100\% RDF + (5t vermicompost + 2.5t Poultry manure) \\
\hline T5 & 75\% RDF + 25\% through FYM \\
\hline T7 & 75\% RDF +25\% through vermicompost \\
\hline T8 & 75\% RDF + 25\% through poultry manure \\
\hline T9 & $50 \% \mathrm{RDF}+50 \%$ through FYM \\
\hline T10 & $50 \% \mathrm{RDF}+50 \%$ through Vermicompost \\
\hline T11 & $50 \% \mathrm{RDF}+50 \%$ through Poultry manure \\
\hline T12 & $50 \% \mathrm{RDF}+50 \%$ through (Vermicompost + Poultry manure) \\
\hline
\end{tabular}


Table.2 Effect of organic manures and inorganic fertilizers on various growth, yield and quality related traits in Bottle gourd

\begin{tabular}{|c|c|c|c|c|c|c|c|c|c|c|c|c|c|c|}
\hline $\mathbf{s}$ & $\begin{array}{c}\text { Treatment } \\
\text { combinations }\end{array}$ & $\begin{array}{l}\text { Vine } \\
\text { length } \\
(\mathbf{m})\end{array}$ & $\begin{array}{c}\text { No. of } \\
\text { branches/ } \\
\text { plant }\end{array}$ & $\begin{array}{l}\text { Days to first } \\
\text { male flower } \\
\text { appearance }\end{array}$ & $\begin{array}{l}\text { Days to first } \\
\text { female flower } \\
\text { appearance }\end{array}$ & $\begin{array}{c}\text { Days to } \\
\text { first } \\
\text { picking }\end{array}$ & $\begin{array}{l}\text { Avg. fruit } \\
\text { length }(\mathrm{cm})\end{array}$ & $\begin{array}{l}\text { Avg. fruit } \\
\text { weight(g) }\end{array}$ & $\begin{array}{l}\text { Diameter } \\
\text { of fruit(cm) }\end{array}$ & $\begin{array}{c}\text { No. of } \\
\text { fruits } \\
\text { per } \\
\text { plant }\end{array}$ & $\begin{array}{l}\text { Fruit yield } \\
\text { per } \\
\text { plant(kg) }\end{array}$ & $\begin{array}{l}\text { Avg. } \\
\text { Yield } \\
\text { per } \\
\text { t/ha }\end{array}$ & TSS & $\underset{\mathrm{C}}{\text { Vitamin }}$ \\
\hline To & $\begin{array}{c}\text { Control [RND (RDF } \\
(120: 60: 60 \mathrm{~kg} \mathrm{NPK})) \\
+20 \mathrm{t} \text { FYM] }\end{array}$ & 4.57 & 7.88 & 82.2 & 86.66 & 88.58 & 25.7 & 1.28 & 14.57 & 9.41 & 12.03 & 15.27 & 2.65 & 5.16 \\
\hline T1 & $\begin{array}{l}100 \% \text { RND through } \\
\text { chemical fertilizers }\end{array}$ & 6.33 & 10.22 & 76.74 & 78.45 & 82.43 & 32.52 & 1.67 & 18.57 & 10.33 & 17.25 & 21.9 & 3.21 & 6.29 \\
\hline $\mathbf{T} 2$ & $\begin{array}{l}100 \% \mathrm{RDF}+10 \mathrm{t} \\
\text { vermicompost }\end{array}$ & 6.84 & 11.21 & 74.95 & 76.77 & 79.5 & 33.53 & 1.55 & 16.8 & 13.5 & 20.93 & 26.57 & 3.42 & 6.13 \\
\hline T3 & $\begin{array}{l}100 \% \mathrm{RDF}+5 \mathrm{t} \\
\text { Poultry manure }\end{array}$ & 6.44 & 11.61 & 73.54 & 75.52 & 79.53 & 31.46 & 1.47 & 16.05 & 19.42 & 28.62 & 36.34 & 4.08 & 6.47 \\
\hline T4 & $100 \% \mathrm{RDF}+$ & 5.84 & 11.21 & 72.02 & 74.25 & 78.48 & 30.42 & 1.41 & 20.04 & 14.51 & 35.13 & 44.61 & 3.75 & 5.49 \\
\hline T5 & $\begin{array}{l}75 \% \text { RDF + 25\% } \\
\text { through FYM }\end{array}$ & 5.92 & 12.1 & 77.98 & 76.88 & 79.65 & 38.44 & 1.52 & 19.48 & 18.56 & 28.21 & 35.82 & 4.12 & 6.49 \\
\hline T6 & $\begin{array}{l}75 \% \mathrm{RDF}+25 \% \\
\text { through vermicompost }\end{array}$ & 6.69 & 12.01 & 71.78 & 75.38 & 79.77 & 35.49 & 1.54 & 19.19 & 16.55 & 26.01 & 33.03 & 3.85 & 6.78 \\
\hline $\mathbf{T 7}$ & $\begin{array}{l}75 \% \mathrm{RDF}+25 \% \\
\text { through poultry } \\
\text { manure }\end{array}$ & 6.43 & 11.74 & 75.77 & 79.85 & 78.51 & 34.32 & 1.59 & 19.6 & 13.34 & 24.37 & 30.95 & 3.81 & 6.59 \\
\hline T8 & $\begin{array}{c}75 \% \text { RDF }+25 \% \\
\text { through } \\
\text { (Vermicompost }+ \\
\text { Poultry manure) }\end{array}$ & 7.39 & 12.31 & 69.39 & 74.25 & 78.4 & 41.54 & 1.79 & 20.23 & 23.51 & 35.78 & 45.43 & 4.36 & 7.1 \\
\hline T9 & $\begin{array}{l}50 \% \text { RDF }+50 \% \\
\text { through FYM }\end{array}$ & 6.91 & 11.85 & 70.44 & 74.36 & 80.31 & 35.45 & 1.7 & 18.51 & 20.21 & 34.43 & 43.72 & 4.27 & 5.35 \\
\hline T10 & $\begin{array}{l}50 \% \text { RDF }+50 \% \\
\text { through Vermicompost }\end{array}$ & 5.79 & 11.69 & 72.39 & 75.15 & 81.53 & 39.58 & 1.57 & 18.53 & 22.42 & 28.48 & 36.16 & 3.52 & 5.55 \\
\hline T11 & $\begin{array}{c}50 \% \mathrm{RDF}+50 \% \\
\text { through Poultry } \\
\text { manure }\end{array}$ & 6.14 & 11.55 & 72.27 & 76.52 & 85.59 & 40.47 & 1.53 & 17.51 & 18.58 & 26.32 & 33.42 & 3.87 & 5.54 \\
\hline T12 & $\begin{array}{c}50 \% \mathrm{RDF}+50 \% \\
\text { through } \\
\text { (Vermicompost }+ \\
\text { Poultry manure) }\end{array}$ & 7.46 & 12.44 & 68.72 & 72.45 & 78.37 & 42.48 & 1.83 & 21.08 & 25.43 & 36.14 & 45.89 & 4.79 & 7.26 \\
\hline & F-Test & S & $\mathrm{S}$ & $S$ & S & $\mathrm{S}$ & S & S & $\mathrm{S}$ & S & S & S & S & S \\
\hline & C.D at $5 \%$ & 0.645 & 1.753 & 1.358 & 0.561 & 0.3 & 0.218 & 0.132 & 0.972 & 0.296 & 2.458 & 3.122 & 0.282 & 0.376 \\
\hline & SEd (+) & 0.313 & 0.849 & 0.658 & 0.272 & 0.145 & 0.106 & 0.06 & 0.471 & 0.143 & 1.191 & 1.513 & 0.137 & 0.182 \\
\hline & $\mathrm{CV}$ & 6.018 & 9.149 & 1.094 & 0.43 & 0.22 & 0.364 & 4.997 & 3.122 & 1.011 & 5.362 & 5.362 & 4.377 & 3.62 \\
\hline
\end{tabular}


Table.3 Benefit cost ratio of various treatment combinations in Bottle gourd cultivation

\begin{tabular}{|c|c|c|c|c|c|c|}
\hline $\begin{array}{c}\text { Treatments } \\
\text { Symbols }\end{array}$ & $\begin{array}{c}\text { Yield } \\
\text { (t/ha) }\end{array}$ & $\begin{array}{c}\text { Selling } \\
\text { Rate (Rs/t) }\end{array}$ & $\begin{array}{c}\text { Gross } \\
\text { return } \\
\text { (Rs/t) }\end{array}$ & $\begin{array}{c}\text { Cost of } \\
\text { cultivation }(\mathbf{R s .})\end{array}$ & $\begin{array}{c}\text { Net return } \\
\text { (Rs/t) }\end{array}$ & $\begin{array}{c}\text { Benefit cost } \\
\text { ratio }\end{array}$ \\
\hline To & 15.27 & 8000 & 122160 & 95772 & 26388 & 1.280 \\
\hline T1 & 21.9 & 8000 & 175200 & 122100 & 53100 & 1.430 \\
\hline T2 & 26.57 & 8000 & 212560 & 162100 & 50460 & 1.310 \\
\hline T3 & 36.34 & 8000 & 290720 & 97100 & 193620 & 2.990 \\
\hline T4 & 33.42 & 8000 & 267360 & 125518 & 141842 & 2.130 \\
\hline T5 & 35.82 & 8000 & 286560 & 117228 & 169332 & 2.440 \\
\hline T6 & 33.03 & 8000 & 264240 & 165518 & 98722 & 1.600 \\
\hline T7 & 30.95 & 8000 & 247600 & 102018 & 145582 & 2.430 \\
\hline T8 & 45.43 & 8000 & 363440 & 1255118 & 237922 & 2.900 \\
\hline T9 & 43.72 & 8000 & 349760 & 106728 & 243032 & 2.200 \\
\hline T10 & 44.61 & 8000 & 356880 & 128936 & 227944 & 2.770 \\
\hline T11 & 36.16 & 8000 & 289280 & 116436 & 172844 & 2.480 \\
\hline T12 & 45.89 & 8000 & 367120 & 167228 & 199892 & 3.280 \\
\hline
\end{tabular}

The reduction in days to male and female flower initiation was due to stimulating effect of phosphorus on growth hormones which induce early flowering (Singh and Ashrey, 2005). On the other hand, plants of the plots with addition of manure and bio-fertilizers along with inorganic fertilizers took comparatively lesser days for initiation of male and female flowers and minimum number of nodes at which first male and female flower appeared. Similar kind of result has been revealed in a study on integrated nutrient management in cucumber by Bindyia et al., (2006), The present results are in harmony with the findings of Prasad et al., (2009) and Suresh Kumar and Karuppaiah (2008) in bitter gourd and Singh and Teena Rani (2012) in bottle gourd. Maximum days taken for first male and female flower appearance $(82.20$ and 86.66 days, respectively) were with treatment combination of RDF of NPK and 20 tonnes of
FYM (T0). The decrease in days for initiation of male and female flowers was due to the stimulating effect of phosphorus on growth hormones that induce early flowering (Singh and Ashrey, 2005). On the other hand, the plants of the plots with the addition of organic manures along with inorganic fertilizers, took comparatively fewer days for the initiation of male and female flowers. Similar results have been found in a study by Bindyia et al., (2006) on integrated nutrient management in cucumber, which is consistent with the results of Prasad et al., (2009) and Suresh Kumar and Karuppaiah (2008) in bitter gourd and Singh and Teena Rani (2012) in bottle gourd.

Impact of different nutrient treatment on yield and yield attributing characters of bottle gourd

Table 2 presents the yield attributing characters such as days of first picking, 
average fruit length $(\mathrm{cm})$, average fruit weight $(\mathrm{g})$, fruit diameter $(\mathrm{cm})$, number of fruits per plant, fruit yield per plant and average yield ( $\mathrm{t} / \mathrm{ha}$ ) Maximum fruit length $(42.48 \mathrm{~cm})$, maximum fruit weight $(1.83 \mathrm{~g})$, maximum fruit diameter $(21.08 \mathrm{~cm})$ and higher number of fruits per plant (25.00) in treatment 12 (50 percent $\mathrm{RDF}+50$ percent through (vermicompost + poultry manure) showed a significant favourable change in yield attributes towards minimum days after first picking (78.00 days), higher fruit yield per plant $(36.14 \mathrm{~kg})$ and maximum yield per hectare (33.42t/ha). The different physiological and metabolic processes, particularly protein metabolism, are due to the luxurious supply of nitrogen, phosphorus, potash, vermicompost, FYM and poultry manure and their absorption effects (Sundararasu 2017).

The translocation to the fruiting nodes of these nutrients results in higher fruiting and fruit growth and yield. Similar findings with respect to nitrogen and phosphorus on yield attributes were also reported by Anjanappa et al., (2012) and Thriveni et al., (2015). When inorganic nutrient sources are applied in combination with FYM, vermicompost and poultry manure contribute favourably to plant growth by producing more carbohydrates. The flow of assimilates to sink was high in this situation and could be the reason for higher fruit size and fruit yield. In addition, fruit length and fruit diameter exercised positively on fruit weight under $\mathrm{T}_{12}$ (Bahadur et al., 2006).

Impact of different nutrient treatment on bottle gourd quality characteristics

In terms of Total Soluble Solid (TSS) treatment $\mathrm{T}_{12} \quad(50 \% \mathrm{RDF}+50 \%$ vermicompost + poultry manure) recorded maximum $\left(4.79^{\circ}\right.$ Brix) TSS of fruit, followed by $\mathrm{T} 8(75 \% \mathrm{RDF}+25 \%$ vermicompost $\&$ poultry manure) with $\left(4.36^{\circ}\right.$ Brix $)$ TSS of fruit, whereas minimum TSS of fruit $\left(2.65^{\circ}\right.$ Brix) was recorded in treatment $\mathrm{T}_{0}$ (control).

In terms of Vitamin $\mathrm{C}$ treatment $\mathrm{T}_{12}(50 \%$ $\mathrm{RDF}+50 \%$ vermicompost + poultry manure) recorded maximum (7.26\%) Vit-C of fruit, followed by $\mathrm{T}_{8} \quad(75 \% \mathrm{RDF}+25 \%$ vermicompost \& poultry manure) with $(7.10 \%)$ Vit-C of fruit, whereas minimum vitamin $\mathrm{c}$ of fruit $(5.16 \%)$ was recorded in treatment $\mathrm{T}_{0}$ (control). These findings are in accord with Chaudhary et al., (2019) and Imnatemsuet al., (2020).

\section{Impact of different nutrient treatment on economic analysis (B:C ratio) of bottle gourd}

In terms of economic analysis, maximum gross return Rs. 367120.00 and Net Return Rs. 199892.00 was recorded in treatment $\mathrm{T}_{12}$ $(50 \% \mathrm{RDF}+50 \%$ vermicompost + poultry manure) and maximum benefit cost ratio of 1:3.28 was recorded in treatment $\mathrm{T}_{12}$ followed by treatment $\mathrm{T}_{8} \quad(75 \% \mathrm{RDF}+25 \%$ vermicompost \& poultry manure) with 1:2.90 and minimum gross return, net return and cost benefit ratio (Rs. 122160.00, Rs. 26388.00 and 1:1.28 respectively) was recorded in treatment $\mathrm{T}_{0}$ (Control, $\mathrm{RDF}+20 \mathrm{t}$ FYM).These conclusions were also derived by Singh and Teena (2012) and Singh et al., 2012.

\section{References}

Anjanappa M., Venkatesha J., and Suresh K. B., 2012. Growth, yield and quality attributes of cucumber ( $\mathrm{Cv}$. Hassan local) as influenced by integrated nutrient management grown under protected condition. Vegetable Science; 39(1): 47-50.

Bahadur A., Singh J., Singh K. P., Upadhyay 
A. K., and Rai M., 2006. Effect of organic amendments and biofertilizers on growth, yield and quality attributes of Chinese cabbage (Brassica perkinensis). Indian J. of Agri. Sci.; 76: 596-98.

Balai R. C., Meena L. R. and Sharma S. C., 2017. Effect of different levels of nitrogen and phosphorus on cowpea [Vigna unguiculata (L.) Walp] under rainfed conditions of Rajasthan. J. of Agri. and Ecology, 3:19-24.

Bindiya Y., Reddy I. P., Srihari D., Reddy R. S., and Narayanamma M., 2006. Effect of different sources of nutrition on soil health, bacterial population and yield of cucumber. J. of Research, ANGRAU; 34: 12-17.

Chaudhary S. K., Yadav S. K., Mahto D. K., Azmi N. Y., Ranjan A. and Sharma R. P., 2019. Impact of organic and inorganic sources of nutrients on growth, yield attributes and yield of bottle gourd (Lagenaria siceraria (Mol.) Standl.) in Bihar. J. of Agri. Search.; 6 (Special):54-58.

Das R., Mandal A. R., AnujaPriya S. P., Das J., and Kabiraj., 2015. Evaluation of intergrated nutrient management on the performance of Bottle gourd. J. Appl. and Natural Sci., 7(1): $18-25$.

Imnatemsu, Neelam Khare, Sandeep R., and Ronald D., 2020. Effect of Organic and Inorganic Fertilizers on Growth and Yield of Bottle Gourd (Lagenaria siceraria) Under Teak Based Agroforestry System. Ind. J. Pure App. Biosci. 8(3), 388-395.

Nagar M., Soni A. K., Sarolia D. K., and Saini H. R., 2017. Effect of organic manures and different levels of NPK on growth and quality of bottle gourd [Lagenaria siceraria (Mol.) Standl.] J. of Agri. and Ecology. 4: 44-50

Nitin K., and Saravanan S. S., 2019. Effect of organic and inorganic fertilizer on the growth and yield of bottle gourd
[Lagenaria siceraria Mol. Standl.].The Pharma Innovation Journal; 8(7): 593597

Pandey S. K., Singh A. B., Singh R., and Singh M. C., 2009. Effect of organic manures and bio- fertilizers on biomass distribution, growth and yield of okra. Vegetable Science; 36(3): 415-17.

Sangeeta S., Champa L. R., Ahmad F., Singh V. K., Kumari R., and Kumari A., 2018. Effect of organic and inorganic fertilizers on growth, yield and quality attributes of Hybrid Bitter gourd (Momordica charantia L.). Int. J. Curr. Microbiol. App. Sci., 7(4): 2256-2266.

Sarhan T. Z., Ghurbat H., Mohammed and Jiyan A. T., 2011. Effect of bio and organic fertilizers on growth, yield and fruit quality of summer squash. Sarhad J. of Agri.; 27(3): 2011.

Satish S. B., Bose1 U. S. and Singh S. S., 2017. Impact of Different Organic and Inorganic Fertilizers on Sustainable Production of Bottle gourd (Lagenaria siceraria L.) Int. J. Pure App. Biosci., 5 (2): 1089-1094.

Singh D. P., Mishra V. C., Prakash H. G. and Mishra O., 2012. Role of organic farming on yield and economics of Bottle gourd and vegetable pea. Int. J. of Agri. Sci., 8(1): 165-167.

Singh R., and Asrey R., 2005. Integrated nutrient management in tomato (Solanum lycopersicum L.) under semiarid region of Punjab. Vegetable Science; 32(2):194-195.

Singh V. K., and Teena R. V. K., 2012. Effect of integrated nutrient management on economics in bottle- gourd (Lagenaria siceraria L.). Environment and Ecology; 30(4A):1410-1412.

Sundararasu K. 2017. Effect of vermicompost and Vermiwash on growth and yield of Bottle gourd, Lagenaria siceraria. Int. J. of Applied and Pure Sci. and Agri., 3(10):19-24. 
Sureshkumar R. and Karuppaiah P., 2008. Effect of integrated nutrient management on growth and yield of bitter gourd (Momordica charantia L.) type Mithipagal. Plant Archives; 8(2).867-868.

Thriveni V., Mishra H. N., Pattanayak S. K.,
Sahoo G. S. and Thomson T., 2015. Effect of inorganic, organic fertilizers and biofertilizers on growth, flowering, yield and quality attributes of bitter gourd (Momordica charantia L.). Int. J. of Farm Sci.; 5(1): 24-29.

\section{How to cite this article:}

Medipalli Pravallika and Deepanshu. 2020. Effect of Organic Manures and Inorganics Fertilizers on Growth and Yield of Bottle Gourd (Lagenaria siceraria Mol.) standl. Int.J.Curr.Microbiol.App.Sci. 9(12): 2884-2892. doi: https://doi.org/10.20546/ijcmas.2020.912.343 